\title{
Retention of permanent incisors by mesiodens: a family affair
}

\author{
Ma Mercedes Gallas, ${ }^{1}$ and A García, ${ }^{2}$
}

\begin{abstract}
The term mesiodens refers to a supernumerary tooth that is present in the midline of the maxilla between the two central incisors. One or two mesiodentes may be present. We present a rare case of two sisters, in both of whom a pair of mesiodentes caused the retention of permanent incisors. They were referred to our hospital with asymptomatic delayed eruption of upper incisors. This article is written to point out genetic factors as the possible origin of supernumerary teeth.
\end{abstract}

$T^{t}$ is widely assumed that the development Iof supernumerary teeth may involve a genetic factor. ${ }^{1}$ Supernumerary teeth are relatively common in the general population and appear to be more likely to occur in patients with a family history of such teeth.

In the Caucasian population the incidence of supernumerary teeth ranges from $1 \%$ to $3 \%$. The mesiodens is the most frequent supernumerary tooth with a prevalence of $0.15 \%$ to $1.9 \% .^{2}$ Mesiodens appears to be more common in males than in females with a male-female ratio of $2: 1 .^{3}$ Familial occurrence of mesiodens is reported to involve more than one sibling, or one generation. ${ }^{2,4-6}$ In some cases, this anomaly has also been seen in more than one generation. ${ }^{7}$

There are many publications that focus on clinical, radiological and surgical or surgical-orthodontic aspects of the treatment of mesiodentes. However, the etiology and the genetic considerations of this dental anomaly remains unclear.

In this report, we present a rare case of two sisters, in both of whom a pair of mesio-

\footnotetext{
${ }^{1}$ Research Assistant of Oral Surgery Unit, School of

Dentistry, Faculty of Medicine and Dentistry,

University of Santiago de Compostela, Spain

${ }^{2}$ Chief of Section, Department of Maxillofacial

Surgery, Hospital General de Galicia, Santiago de

Compostela, and Senior Lecturer in Maxillofacial

Surgery, University of Santiago de Compostela, Spain

Correspondence to: $M^{a}$ Mercedes Gallas, Facultad de Medicina y Odontología, Rúa Entrerríos, S/N,

Santiago de Compostela, C.P.: 15705, Spain

e-mail:zodousc@usc.es

REFEREED PAPER
}

Received 09.03.99; accepted 13.08.99

(c) British Dental Journal 1999; 188: 63-64

\section{In brief}

- Although uncommon, anterior maxillary supernumerary teeth (mesiodentes) are the most frequent supernumerary teeth.

- The etiology of this dental anomaly

- There probably exists a familial disposition.

- This paper will try to underline the importance of genetics as a key factor in the development of supernumerary teeth.

dentes caused the retention of permanent incisors. Unfortunately, no information was available concerning similar anomalies among their forebears.

\section{Case reports}

Case 1

In a 13-year-old-girl, referred with delayed eruption of the permanent central maxillary incisors, both deciduous central maxillary incisors were present. A review of her medical history showed nothing remarkable. Radiography showed that two supernumerary teeth in the anterior maxilla were preventing the eruption of the permanent incisors. The supernumerary teeth were removed surgically, and removal of bone was performed to facilitate the rapid eruption of the permanent incisors.

\section{Case 2}

In the maxillary arch of the 8-year-old-sister of the subject of Case 1, the permanent central incisors had erupted without the deciduous central incisors having exfoliated. remains unclear.
Radiography showed a pair of supernumerary teeth in the same positions as in Case 1, though with less developed roots. The general morphology and position of the supernumerary teeth were identical in the radiographs of both sisters (Fig. 1 and Fig. 2). Again, surgical removal of the supernumerary teeth was followed by removal of bone.

In neither case did histological examination show the dental tissues of the supernumerary teeth to differ from those of normal teeth.

\section{Discussion}

Several theories have been proposed for the etiology of hyperdontia: theory of differentiation, theory of concrescence, post permanent theory, dichotomy theory and hyperactivity theory. However the hyperactivity theory, which states that supernumerary teeth are derived from independent local hyperactivity of the dental lamina, has been more accepted. According to this hypothesis the lingual extension of an additional tooth bud leads to a eumorphic mesiodens, while the rudimentary form arises from proliferation of epithelial remnants of the dental lamina induced by pressure of the dentition. ${ }^{8,9}$

There appears to be evidence to suggest a familial predisposition to producing extra teeth. Many published cases of supernumerary teeth mention reincidence within the same family, but without investigating this aspect in detail. Such cases include that of two brothers, in one of whom a mesiodens appeared with the deciduous teeth and in the other the mesiodens appeared at the same time as the permanent incisors. ${ }^{5}$ In another case, two brothers, aged 11 and 12 years, one of whom had typical conical mesiodens and the other who had an unusual molariform mesiodens (mesiodens with coronal morphology vaguely similar to that of a molar) $;^{6}$ and that of a brother and a sister, one with an inverted mesiodens and one with an uninverted mesiodens. ${ }^{2}$ The latter two reports did not mention the absence of similar abnormalities in the parents. Sedano et al. ${ }^{2}$ nevertheless suggested that mesiodens is an autosomal dominant trait with lack of penetrance in some genera- 
tions. Bruning et al. ${ }^{10}$ has even proposed the possibility of sex-linked inheritance caused by the existence of a sex predominance of males over females. Cadenat et $a l^{7}$ pointed out that there is a recessive gene on an autosome and a gene on the inhibiting $\mathrm{X}$ chromosome. These authors refuted the theory of mutation and finally reported the case of mesiodens in two non-identical twins and in their grandfather. Although no investigation proved the hereditary condition of the mesiodens, it is quite possible, in view of the patients showing a familial disposition. ${ }^{3}$ Many authors suggested inheritance as a key factor in the development of mesiodens. ${ }^{2,3,7,10}$ Brook $^{11}$ postulated a multifactorial polygenic model of quasi-continuous traits for simultaneous consideration of supernumeraries, megadontia, oligodontia and microdontia. Nislander and Sujaku ${ }^{12}$ compiled data for supernumerary teeth, and theorised that this trait may be associated with an autosomal recessive gene with lesser penetrance in the female. Further support of a genetic component in hyperdontia is evidenced by their simultaneous occurrence in identical twins. ${ }^{13}$

The presence of hyperdontia may be associated with various developmental disorders. The two most common disorders with a significant incidence of a supernumerary teeth are cleft lip and cleft palate, ${ }^{14}$ and cleidocranial dysplasia. ${ }^{15}$ Less frequent developmental disorders are Gardner's Syndrome, Fabry-Anderson's Syndrome, chondroectodermal dysplasia (Ellis-van Greveld Syndrome), incontinentia pigmenti, and tricho-rhino-phalangeal syndrome. ${ }^{1,8,16,17}$ However, neither of our patients had any symptoms suggestive of a syndromic background.

Human dental eruption is known to be a dynamic interaction between genetics and the environment, each one affecting and being affected by the other. Therefore, changes in the initial stages result in hyperdontia, such as mesiodens, or hypodontia. From our point of view a more detailed investigation into family history of patients with mesiodentes is needed.

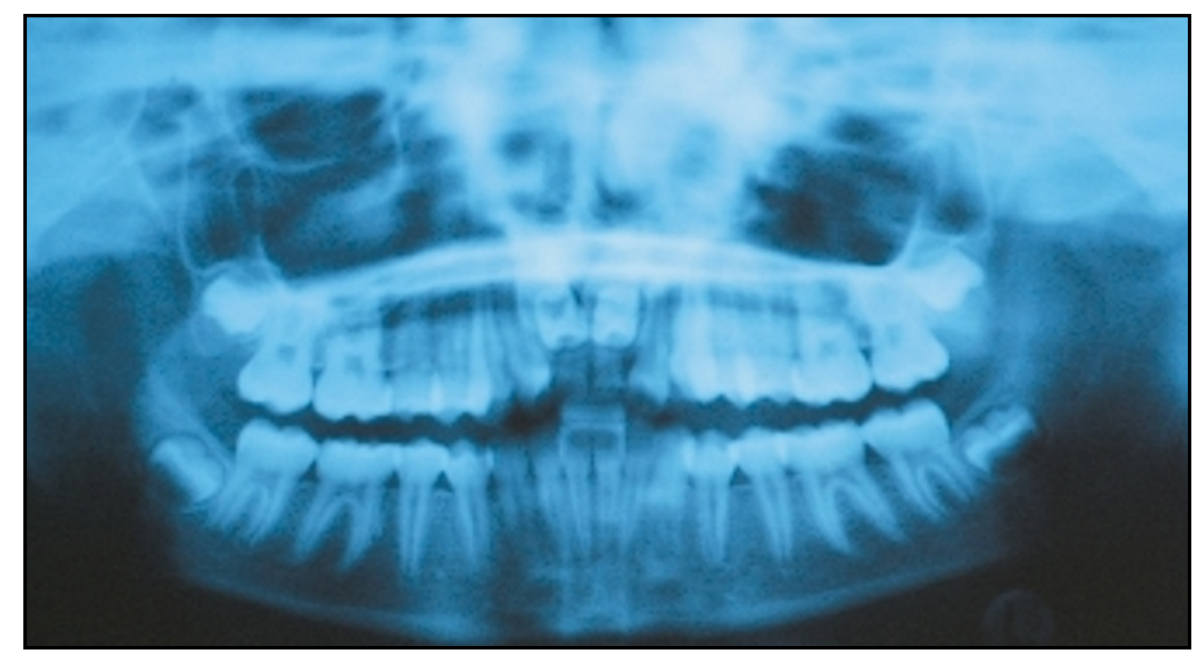

Fig. 1 Orthopantomograph Case 1

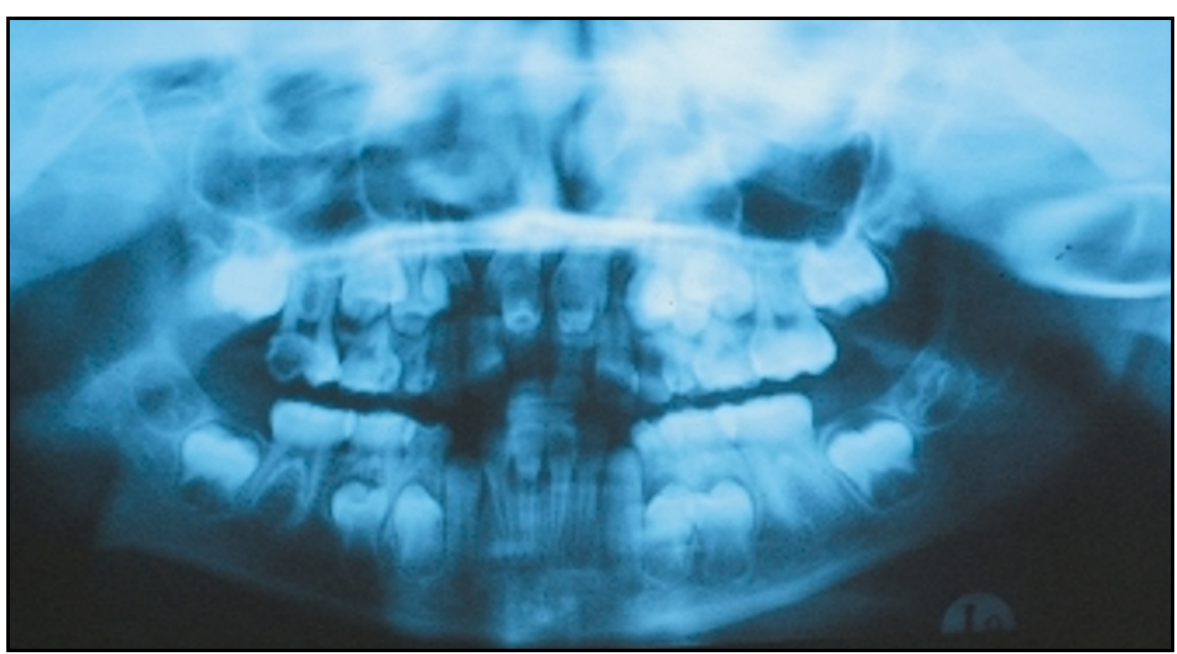

Fig. 2 Orthopantomograph Case 2

1 Gorlin R J, Goldman H M. Thoma's Oral Pathology. 6th ed. St. Louis-Toronto-Princeton Barcelona: Salvat Ed. C.V. Mosby. 1973: 124-126.

2 Sedano H O, Gorlin R J. Familial occurrence of mesiodens. Oral Surg Oral Med Oral Pathol 1969; 27: 360-362.

3 Stellzig A, Basdra E K, Komposch G. Mesiodentes: incidence, morphology, etiology. J Orofac Orthop 1997; 58: 144-153.

4 Marya C M, Kumar B R. Familial occurrence of mesiodentes with unusual findings: case reports. Quintessence Int 1998; 29: 49-51.

5 Molleda Medrano N. Algunos casos de dientes supernumerarios. Rev Esp Estom 1956; MayoJunio: 244-248.

6 Nadal-Valldaura A. Un caso de dos hermanos con dientes supernumerarios. Rev Esp Estom 1961; 9: 101-104.

7 Cadenat H, Combelles R, Fabert G, Clouet M. Mesiodens and heredity (Mesiodens et heredite). Rev Stomatol Chir Maxillofac 1977; 78: 341-346.

8 Sykaras S N. Mesiodens in primary and permanent dentition. Oral Surg 1975; 39 : 870-874.

9 Pindborg J J. Pathology of Dental Hard Tissues. Philadelphia: W. B. Saunders Company. 1970; 26-33.
10 Bruning L J, Dunlop L, Mergele M E. A report of supernumerary teeth in Houston, Texas school children. J Dent Child 1957; 24: 98 105.

11 Brook A H. A unifying aetiological explanation for anomalies of human tooth number and size. Archs Oral Biol 1984; 29: 373-378.

12 Nislander J D, Sujaku C. Congenital anomalies of teeth in the Japanese children. Amer J Phys Anthrop 1963; 21: 569-574.

13 Rubin M M, Nevins A, Berg M, Borden B. A comparison of identical twins in relation to three dental anomalies: multiple supernumerary teeth, juvenile periodontosis, and zero caries incidence. Oral Sur 1981; 52: 391-394.

14 Böhn A. Dental anomalies in harelip and cleft palate. Acta Odontol Scand 1963; 21: 1-114. Supp. 38.

15 Richardson A, Deussen F F. Facial and dental anomalies in cleidocranial dysplasia: a study of 17 cases. Int J Paediatr Dent 1994; 4: 225231.

16 Regattieri L R, Parker J L. Supernumerary teeth associated with Fabry-Anderson's Syndrome. Oral Surg 1973; 35: 432-433.

17 Gorlin R J, Cohen M M, Wolfson J. TrichoRhino-Phalangeal Syndrome. Am J Dis Child 1969; 118: 595-599. 